\title{
Analisis Data Research dan Development Pendidikan Islam
}

\author{
Suwandi \\ Sekolah Tinggi Agama Islam Unggul Indonesia Pekanbaru \\ Email: ustadzsuwandiaksi@gmail.com
}

\begin{abstract}
Abstrak
Tujuan Penelitian ini adalah untuk mengetahui Analisis Data Research dan Development Pendidikan Islam. Jenis penelitian yang digunakan dalam penelitian ini adalah penelitian kualitatif. Bob dan Taylor, mendefinisikan metodologi kualitatif adalah prosedur penelitian yang menghasilkan data deskriptif berupa kata-kata tertulis atau lisan dari orangorang dan perilaku yang dapat diamati. Penelitian kualitatif adalah penelitian untuk menjawab permasala han yang memerlukan pemahaman secara mendalam dalam konteks waktu dan situasi yang bersangkutan, dilakukan secara wajar dan alami sesuai dengan kondisi objektif di lapangan tanpa adanya manipulasi, serta jenis data yang dikumpulkan terutama data kualitatif. hasil penelitian dapat disimpulkan sebagaiberikut; Penelitian Research and Development adalah suatu langkah untuk mengem bangkan suatu produk baru atau menyempurnakan produk yang sudah ada dan menguji keefekitifannya, serta bersifat longitudinal atau bertahap dapat multy years. Penelitian Research and Development menggunakan teknik analisis data kuantitatif dan kualitatif. Pemilihan teknik analisis data ini sangat tergantung pada jenis data dan tujuan penelitiannya. 1. Teknik analisis data kualitatif terbagi menjadi dua, yaitu : (1) teknik kualitatif hanya mendeskripsikan fenomena atau fakta saja tanpa memberi makna atas fenomena tersebut., (2) teknik kualitatif yang bertujuan memaknai fenomena atau fakta secara mendalam. 2. Teknik analisis data kuantitatif yang menggunakan statistika sebagai instrumennya dibedakan menjadi dua, yaitu: (1) analisis data kuantitatif dengan teknik statistik deskriptif, dan (2) analisis data kuantitatif dengan statistik inferensial.
\end{abstract}

Key Words: Analisis Data; Research; Development; Pendidikan Islam

\section{PENDAHULUAN}

Penelitian adalah proses ilmiah yang mencakup sifat formal dan intensif. Karakter formal dan intensif karena mereka terikat dengan aturan, urutan, maupun cara penyajiannya agar memperoleh hasil yang diakui dan bermanfaat bagi kehidupan manusia. Intensif dengan menerapkan ketelitian dan ketepatan dalam melakukan proses penelitian agar memperoleh hasil yang dapat dipertanggung jawabkan, memecahkan problem malalui hubungan sebab dan akibat, dapat diulang kembali dengan cara yang sama dan hasil sama. Penelitian dan pengembangan merupakan metode penghubung atau pemutus kesenjangan antara penelitian dasar dengan penelitian terapan (Punaji Setyosari, 2010).

Sering dihadapi adanya kesenjangan antara hasil-hasil penelitian dasar yang bersifat teoritis dengan penelitian terapan yang bersifat praktis. Penelitian dan Pengembangan adalah suatu proses atau langkahlangkah untuk mengembangkan suatu produk baru atau menyempurnakan produk yang telah ada. Yang dimaksud dengan produk dalam konteks ini adalah tidak selalu berbentuk hardware (buku, modul, alat bantu pembelajaran di kelas dan laboratorium), tetapi bisa juga perangkat lunak (software) seperti program untuk pengolahan data, pembelajaran di kelas, perpustakaan atau laboratorium, ataupun model-model 
pendidikan, pembelajaran pelatihan, bimbingan, evaluasi, manajemen,dll. (Sawaluddin, dan Muhammad Siddiq, 2020). Didalam penelitian yang bersifat ilmiah maka harus dilakuakan dengan teliti, cermat dan hati-hati. Proses penelitian tidak cukup diselesaikan dalm tempo waktu yang singkat, melainakan memerlukan waktu yang relaif lama (Zainal Arifin, 2012).

Dalam prosesnya juga ada prosedur dan rambu-rambu yang harus diperhatikan. Konsep-konsep dasar penelitian yang meliputi langkah-langkah dan prosedur penelitian harus diketahui oleh peneliti. Dalam menentukan varibel, fokus penelitian (pemetaan variable dan penentuan focus ), populasi, sampel, dan teknik sampling juga harus dapat dikuasai oleh peneliti untuk menghasilkan hasil penelitian yang lebih akurat dan valid. Tidak terkecuali dengan pemahaman akan pentingnya analisis kebutuhan dan analisis data yang juga membutuhkan keuletan dan kepiawaian dalam melakukannya (Dick and Carey, 2001). Hal ini juga tidak boleh diabaikan karena pada tahap ini peneliti harus menentukan jenis penelitiannya. Karena pada dasarnya penerapan analisis kebutuhan dan analisis data berbeda jika jenis penelitiannya berbeda (Nana Syaodih Sukmadinata, 2009).

Banyak metode yang dapat digunakan dalam upaya mengembangkan praktik kependidikan. Salah satu yang saat ini banyak digunakan adalah metode Research and Development atau R \& D. Bahkan beberapa buku penelitian baik versi Bahasa Indonesia maupun Bahasa Inggris sudah banyak yang menyisipkan metode ini dalam bab tersendiri.

Perlu dipahami pula bahwa R\&D merupakan metode penelitian multi tahap bahkan dalam beberapa kasus, penelitian dengan metode ini memakan waktu lebih dari satu tahun, sehingga peneliti perlu untuk lebih terampil dalam merencanakan penelitian ini agar hasil yang diharapkan dapat diperoleh sesuai dengan waktu yang direncanakan. Sesuai dengan namanya, Research \& Developmnet difahami sebagai kegiatan penelitian yang dimulai dengan research dan diteruskan dengan development. Kegiatan research dilakukan untuk mendapatkan informasi tentang kebutuhan pengguna (needs assessment) sedangkan kegiatan development dilakukan untuk menghasilkan perangkat pembelajaran (Sudarwan Danim, 2002).

Tahapan dalam penelitian dan pengembangan (R\&D) dalam penelitian ini secara operasional mengadopsi model Borg \& Gall yang terdiri dari: 1) Potensi dan Masalah; 2) Mengumpulkan Informasi; 3) Pengembangan Model ; 4) Validasi Model ; 5) Revisi Model ; 6) Uji Coba Model; 7) Revisi Model; 8) Uji Coba Lebih Luas; dan 9) Revisi Model Akhir (Sugiyono, 2009). Artikel ini akan membahas mengenai Analisis Data Research dan Development.

Beberapa hal yang akan dibahas antara lain: studi literatur, pengembangan intrumen, penelitian pendahuluan, mengembangkan desain eksperimental dan melakukan uji keefektivan serta efisiensi program yang dikembangkan dalam penelitian.

\section{METODE}

Jenis penelitian yang digunakan dalam penelitian ini adalah penelitian kualitatif. Hal ini terlihat dari prosedur yang ditetapkan yaitu prosedur penelitian yang menghasilkan data deskriptif: ucapan atau tulisan dan perilaku yang diamati dari orang-orang (subjek) itu sendiri (Arief Furchan, 1992). Bob dan Taylor, mendefinisikan metodologi kualitatif adalah prosedur penelitian yang menghasilkan data deskriptif berupa katakata tertulis atau lisan dari orangorang dan perilaku yang dapat diamati (Lexy $\mathbf{J}$ Moleong, 2005). Penelitian kualitatif adalah penelitian untuk menjawab permasala han yang memerlukan pemahaman secara mendalam dalam konteks waktu dan situasi yang 
bersangkutan, dilakukan secara wajar dan alami sesuai dengan kondisi objektif di lapangan tanpa adanya manipulasi, serta jenis data yang dikumpulkan terutama data kualitatif.

\section{HASIL DAN PEMBAHASAN}

\section{Research dan Development}

Metode penelitian

dan

pengembangan atau yang dikenal dengan $\mathrm{R} \& \mathrm{D}$ (research and development) adalah metode penelitian yang digunakan untuk menemukan dan mengembangkan (menghasilkan) produk tertentu, dan menguji keefektifan (validasi) produk tersebut. Untuk dapat menghasilkan produk tertentu digunakan penelitian yang bersifat analisis kebutuhan (digunakan metode survey atau kualitatif) dan untuk menguji keefektifan produk tersebut supaya dapat berfungsi di masyarakat luas, maka diperlukan penelitian untuk menguji keektifan produk tersebut (digunakan metode eksperimen atau PTK) Setelah produk teruji, maka dapat diaplikasikan. Proses pengujian produk dengan eksperimen tersebut dinamakan penelitian terapan (applied research)( Borg. W.R. dan Gall, M.D., 1983)

Penelitian dan pengembangan dalam konteks pendidikan (educational research and development) merupakan sebuah cara yang digunakan untuk mengembangkan yaitu merencanakan, merumuskan, memvalidasi, dan merevisi suatu produk pendidikan. Oleh karena itu, R\&D berbeda dengan penelitian biasa yang hanya menghasilkan saran-saran bagi perbaikan, $\mathrm{R} \& \mathrm{D}$ menghasilkan produk yang langsung bisa digunakan. Menurut Sugiyono (2009), produkproduk pendidikan yang dihasilkan dapat berupa kurikulum yang spesifik untuk keperluan pendidikan tertentu, metode mengajar, media pendidikan, buku ajar, modul, kompetensi tenaga kependidikan, sistem evaluasi, model uji kompetensi, penataan ruang kelas untuk model pembelajar tertentu, model unit produksi, model manajemen, sistem pembinaan pegawai, sistem penggajian dan lain-lain.

Menurut Mulyatiningsih (2012), penelitian dan pengembangan bertujuan untuk menghasilkan produk baru melalui proses pengembangan. Menurut Puslitjaknov-Balitbang Depdiknas metode penelitian dan pengembangan memuat tiga komponen utama, yaitu 1) model pengembangan, 2) prosedur pengembangan, 3) uji coba produk. Sedangkan menurut Anik Ghufron (2007), penelitian dan pengembangan adalah model yang dipakai untuk meningkatkan mutu pendidikan dan pembelajaran yang mampu mengembangkan berbagai produk pembelajaran.

Berdasarkan pendapat diatas dapat disimpulkan bahwa penelitian pengembangan atau research and development (R\&D) adalah model penelitian yang bertujuan untuk mengembangkan produk yang diawali dengan riset kebutuhan kemudian dilakukan pengembangan untuk menghasilkan sebuah produk yang telah teruji. Hasil produk pengembangan antara lain: media, materi pembelajaran, dan sistem pembelajaran. Pada penelitian ini mengguna kan jenis penelitian research and development (R\&D)

\section{Teknik Analisis Data}

Kata analysis berasal dari bahasa Greek (Yunani), terdiri dari kata "ana" dan "lysis". Ana artinya atas (above), lysis artinya memecahkan atau menghancurkan. Secara difinitif ialah: "Analysis is a process of resolving data into its constituent components to reveal its characteristic elements and structure" menurut Ian Dey Agar data bisa dianalisis maka data tersebut harus ipecah dahulu menjadi bagian-bagian kecil (menurut element atau struktur), kemudian menggabungkannya bersama untuk memperoleh pemahaman yang baru. Analisa data merupakan proses paling vital dalam sebuah penelitian. Hal ini berdasarkan argumentasi bahwa 
dalam analisa inilah data yang diperoleh peneliti bisa diterjemahkan menjadi hasil yang sesuai dengan kaidah ilmiah.

Maka dari itu, perlu kerja keras, daya kreatifitas dan kemampuan intelektual yang tinggi agar mendapat hasil yang memuaskan. Analisis data berasal dari hasil pengumpulan data. Sebab data yang telah terkumpul, bila tidak dianalisis hanya menjadi barang yang tidak bermakna, tidak berarti, menjadi data yang mati, data yang tidak berbunyi. Oleh karena itu, analisis data di sini berfungsi untuk mamberi arti, makna dan nilai yang terkandung dalam data itu Analisis data disebut juga pengolahan data dan penafsiran data. Analisi data adalah rangkaian kegiatan penelaahan, pengelompokan, sistematisasi, penafsiran dan verivikasi data agar sebuah fenomena memiliki nilai social, akademis dan ilmiah.

Kegiatan dalam analisis data adalah : mengelompokan data berdasarkan variabel dan jenis responden, mentabulasi data berdasarkan variabel dan seluruh responden, menyajikan data tiap variabel yang diteliti, melakukan perhitungan untuk menjawab rumusan masalah dan melakukan perhitungan untuk menguji hipotesis, langkah terakhir tidak dilakukan. Tujuan analisa menurut Sofian Effendi dalam bukunya Metode Penelitian Survai adalah menyederhanakan data dalam bentuk yang lebih mudah ibaca dan diinterpre tasi (Singarimbun, Masri dan Sofian Effendi, 2008). Dalam penelitian strukturalistik, data yang berupa kualitatif (kata-kata) dikuanti fikasikan terlebih dahulu kemudian dianalisis secara statistikan bertujuan untuk menjelaskan fenomena, menguji hipotesis kerja dan mengangkat sebagai temuan berupa verifikasi terhadap teori lama dan teori baru. Sedangkan dalam penelitian naturalistik data bisa berupa kata-kata maupun angka. Data yang bersifat kuantitatif (angka) tidak perlu dikualitatif kan terlebih dahulu dan tidak menguji hipotesis/teori, melainkan untuk mendukung pemahaman yang dilakukan oleh data kualitatif dan menghasil kan teori baru.

Analisis data dalam penelitian dan pengembangan (R\&D) tergantung pada masalah dan desain penelitian yang digunakan. Berdasarkan berbagai model R\&D yang telah disebutkan maka model penelitian dan pengembangan (R\&D) dapat disederhanakan menjadi 3 kategori utama; uji pendahuluan (bersifat hipotetik), pengembangan, dan uji coba produk.

Borg and Gall (dalam Sugiyono, 2009) menyatakan bahwa untuk penelitian analisis kebutuhan sehingga mampu dihasilkan produk yang bersifat hipotetik sering digunakan metode penelitian dasar (basic research) seperti metode survey atau kualitatif. Selanjutnya untuk menguji produk yang masih bersifat hipotetik tersebut, digunakan eksperimen (pre-eksperimen, kuasi-eksperimen, dan eksperimen sesungguhnya) atau class action research (PTK). Setelah produk teruji, maka dapat diaplikasikan. Proses pengujian produk dengan eksperimen tersebut dinamakan penelitian terapan (applied research). Penelitian dan pengembangan bertujuan untuk menemukan, mengembangkan dan memvalidasi suatu produk.

Untuk data kualitatif dapat dianalisis secara deskriptif, sedangkan data kuantitatif harus dilakukan uji statistik berupa uji normalitas dan uji homogenitas. Uji normalitas berfungsi untuk mengetahui apakah sebaran data responden berdistribusi normal ataukah tidak. Uji normalitas akan berpengaruh pada penggunaan alat test statistik dalam uji keefektivan model, apakah akan menggunakan statistik parametrik atau non parametrik. Uji homogenitas digunakan untuk mengetahui apakah kelompok responden berasal dari populasi yang sama atau tidak. Jika data 
hasil perhitungan pada uji normalitas menunjukkan bahwa distribusi data adalah normal, maka analisis statistik yang digunakan untuk uji keefektivan model statistik parametrik.

Sebaliknya jika data berdistribusi tidak normal maka uji keefektivan model menggunakan statistik non parametrik. Statistik nonparametrik untuk uji keefektivan model dengan menggunakan SPSS adalah melalui uji Wilcoxon Signed Rank Test (Prasetyo, 2012). Penelitian ini bisa menggunakan teknik analisis data kuantitatif dan kualitatif. Pemilihan teknik analisis data ini sangat tergantung pada jenis data dan tujuan penelitiannya. Teknik analisis data kualitatif terbagi menjadi dua, yaitu:

1. Teknik kualitatif hanya mendeskripsikan fenomena atau fakta saja tanpa memberi makna atas fenomena tersebut.

2. Teknik kualitatif yang bertujuan memaknai fenomena atau fakta secara mendalam.

Dalam penelitian kualitatif data yang diperoleh dari berbagai sumber dengan menggunakan teknik pengumpulan data yang bermacam-macam (triangulasi), dan dilakukan secara terus menerustersebut mengakibatakan variasi data sangat tinggisekali. Data yang diperoleh pada umumnya adalah data kualitattif sehingga tekniik analisa yang digunakanbelum ada pola yangjelas (Suprayogo Imam, Tobroni, 2001). Oleh Karen itu sering mengalami kesulitan dalam melakukan analisis. Proses analisis dalam penelitian kualitatif dilakukan sejak sebelum memasuki lapangan, selam di lapangan, dan setelah selesai dilapangan. Analisis sebelum dilapangan dilakukan terhadap data hasil studi pendahuluan, atau data skunder yang akan menentukan fokus penelitian. Namun fokus penelitian ini bersifat sementara dan akan berkembang setelah peneliti akan masuk dan selama dilapangan.
Adapun teknik analisis data kuantitatif yang menggunakan statistika sebagai instrumennya dibedakan menjadi dua, yaitu (Andri Setiawan, 2014):

a. Analisis data kuantitatif dengan teknik statistik deskriptif, dan

b. Analisisdatakuantitatifdenganstatistiki nferensial.

Dalam penelitian kuantitatif, analisis data merupakan kegiatan setelah data dari seluruh responden atau sumber data lain terkumpul. Teknik analisis data dalam penelitian kuantitatif menggunakan statistik. Terdapat dua macam statistic yang digunakan untuk menganalisis data dalam penelitian, yaitu statistic deskriptif dan statistic inferensial. Statistic inferensial meliputi statistic parametris dan non parametris.

a. Statistic deskriptif

Statistic deskriptif adalah statistic yang digunakan untuk mengana lisis data dengan cara mendeskripsikan atau menggambarkan data yang telah terkumpul sebagaiamana adanya tanpa bermaksud membuat kesimpulan yang berlaku untuk umum atau generalisasi. Penelitian yang dilakukan pada populasi (tanpa diambil smapelnya) jelas akan menggunakan statistic deskriptif dalam analisisnya.

Tetapi bila penelitian dilakukan pada sampel, maka analisisnya dapat menggunakan statistic despkriptif maupun inferensial. Statistic deskriptif dapat digunakan bila peneliti hanya ingin mendeskripsikan data sampel, dan tidak ingin membuat kesimpulan yang berlaku untuk populasi dimana sampel dambil. Mengenai data dengan statistik deskriptif. eneliti perlu memperhatikan terlebih dahulu jenis datanya. Jika peneliti mempunyai data diskrit, penyajian data yang dapat dilakukan adalah mencari frekuensi mutlak, frekuensi relatif (mencari persentase), serta mencari ukuran tendensi sentralnya yaitu: mode, median dan mean. 
Sesuai dengan namanya, deskriptif hanya akan mendeskripsikan keadaan suatu gejala yang telah direkam melalui alat ukur kemudian diolah sesuai dengan fungsinya. Hasil pengolahan tersebut selanjutnya dipaparkan dalam bentuk angka-angka sehingga memberikan suatu kesan lebih mudah ditangkap maknanya oleh siapapun yang membutuhkan informasi tentang keberadaan gejala tersebut.

Fungsi statistik deskriptif antara lain mengklasifikasikan suatu data variabel berdasarkan kelompoknya masingmasing dari semula belum teratur dan mudah diinterpretasikan maksudnya oleh orang yang membutuh kan informasi tentang keadaan variabel tersebut. Selain itu statistik deskriptif juga berfungsi menyajikan informasi sedemikian rupa, sehingga data yang dihasilkan dari penelitian dapat dimanfaatkan oleh orang lain yang membutuhkan.

Analisi statistic deskriptif dapat dibedakan menjadi : (1) analisis potret data (frekuansi dan presentasi), (2) analisis kecenderungan sentral data (nilai rata-rata, median, dan modus) serta (3) analisis variasi nilai (kisaran dan simpangan baku atau varian):

a) Analisis potret data

Potret data adalah perhitungan frekuensi suatu nilai dalam suatu variabel. Nilai dapat disajikan sebagai jumlah absolute atau presentase dari keseluruhan.

b) Analisis kecenderungan sentral data

1. Nilai rata-rata atau mean biasa diberi symbol $\mathrm{X}$, merupakan nilai ratarata secraa aritmatika dari semua nilai dari variabel yang diukur.

2. Median adalah nilai tengah dari sekumpulan nilai suatu variabel yang telah diurutkan dari nilai terkecil kepada nilai yang tetinggi.

3. Modus (modu) adalah nilai yang paling sering muncul pada suatu distribusi nilai variabel

c) Analisis variasi nilai
Analisis ini dilakukan untuk melihat sebaran nilai dalam distribusi keseluruhan nilai suatu variabel dari nilai tengahnya. Analisis ini untuk melihat seberapa besar nilai-nilai suatu variabel berbeda dari nilainya. Pengukuran variasi nilai biasanya dilakukan dengan melihat kisaran data (range) atau simpangan baku (standar devinatioan).

b. StatistikInferensial

Pemakaian analisis inferensial bertujuan untuk menghasilkan suatu temuan yang dapat digeneralisasikan secara lebih luas ke dalam wilayah populasi. Di sini seorang peneliti akan selalu berhadapan dengan hipotesisnihil (Ho) sebagai dasar penelitiannya untuk diuji secara empirik dengan statistik inferensial. Jenis statistik inferensial cukup banyak ragamnya,Peneliti diberikan peluang sebebas-bebasnya untuk memilih teknik mana yang paling sesuai (bukan yang paling disukai) dengan sifat/jenis data yang dikumpulkan. Secara garis besar jenis analisis ini dibagi menjadi dua bagian. Pertama untuk jenis penelitian korelasional dan kedua untuk komparasi dan/atau eksperimen. Teknik analisis dengan statistic inferensial adalah teknik pengolahan data yang memungkinkan peneliti untuk menerik kesimpulan, berdasarkan hasil penelitiannya pada sejumlah sampel, terhadap suatu populasi yang lebih besar.

Kesimpulan yang diharapkan dapat dibuat biasanya dinayatakan dalam suatu hipotesis. Oleh karena itu, analisis statistik inferensial juga bisa disebut analisis uji hipotesis. Inferensi yang sering dibuat oleh peneliti pendidikan dan ilmu social pada umunya berhubungan dengan upaya untuk melihat perbedaan (beda nilai tengah) dan korelasi, baik anatara dua variabel independent maupun anatara beberapa variabel sekaligus. Selisih nilai tengah ataupun nilai koefisien (correlation coeficient) yang dihasilkan kemudian diuji secara statistic. 
Statistic inferensial, sering juga disebut statistic induktif atau statistic probabilitas, adalah teknik statistic yang digunakan untuk menganalisis data sampel dan hasilnya diberlakukan utuk populasi. Statistic ini akan cocok digunakan bila sampel diambil dari popualsi yang jelas, dan teknik pengambilan sampel dari populasi itu dilakukan secara random. Statistik inferensial fungsinya lebih luas lagi, sebab dilihat dari analisisnya, hasil yang diperoleh tidak sekedar menggambarkan keadaan atau fenomena yang dijadikan obyek penelitian, melainkan dapat pula digeneralisasikan secara lebih luas kedalam wilayah populasi.

Karena itu, penggunaan statistik inferensial menuntut persyaratan yang ketat dalam masalah sampling, sebab dari persyaratan yang ketat itulah bisa diperoleh sampel yang representatif; sampel yang memiliki ciri-ciri sebagaimana dimiliki populasinya. Dengan sampel yang representatif maka hasil analisis inferensial dapat digeneralisasikan ke dalam wilayah populasi. Statistic inferensial meliputi statistic parametris dan non parametris. Statistic parametris digunakan untuk menguji parameter populasi melalui statistic, atau menguji ukuran populasi melalui data sampel.

Parameter populasi itu meliputi : rata-rata dengan notasi $\mu$ (mu), simpangan baku $\sigma$ (sigma) dan varians $\sigma 2$. Dalam statistic pengujian parameter melalui statistic (data sampel) tersebut dinamakan uji hipotesis statistic. Oleh karena itu penelitian yang berhipotesis statistic adalah penelitian yang menggunakan sampel. Sebagai contoh nilai suatu pelajaran 1000 mahasiswa rataratanya 7,5 . Selanjutnya missal dari 1000 orang itu diambil sampel 50 orang, dan nilai rata-rata dari sampel 50 mahasiswa itu 7,5. Hal ini berarti tidak ada perbedaan antara parameter (data popualasi) dan statistic (data sampel). Hanya dalamkenyataannya nilai parameter jarang diketahui. Statistic non parameter tidak menguji parameter populasi, tetapi menguji distribusi (Nuruddin, Khasan, 2014).

Penggunaan statistic parametris dan non parameter tergantung pada asumsi dan jenis data yang akan dianalisis. Statistik parametris memerlukan terpenuhinya banyak asumsi. Asumsi yang utama adalah data yang akan dianalisis harus berdistribusi normal. Selanjutnya dalam penggunaan salah satu tes mengharuskan data dua kelompok atau lebih yang diuji harus homogen, dalam regresi harus terpenuhi asumsi linieritas.statistik non parametris tidak menuntuk terpenuhinya banyak asumsi, misalnya data yang akan dianalisis tidak harus berdistribusi normal. Oleh karena itu statistic non parametris mempunyai kekuatan yang lebih dari statistic non parametris, bila asumsi yang melandasi dapat terpenuhi (Rouf, Muhammad, 2014).

Dalam dunia statistik dikenal setidaknya terdapat empat jenis data hasil pengukuran, yaitu data Nominal, Ordinal, Interval dan Rasio. Masingmasing data hasil pengukuran ini memiliki karakteristik tersendiri yang berbeda antara satu dengan lainnya Penggunaan kedua statistic tersebut juga tergantung pada jenis data yang dianalisis. Statistic parametris kebanyakan digunakan untuk menganalisis data interval dan rasio, sedangkan statistic non parametris kebanyakan digunakan untuk mengana lisis data nominal, ordinal (Van den Akker J, 1999). Jadi untuk menguji hipotesis dalam penelitian kuantitatif yang menggunakan statistic, ada dua hal utama yang harus diperhatikan yaitu, macam data dan bentuk hipotesi yang diajukan. Dalam statistik parametris menggunakan analisis data yang berupa:

a) Data Interval

Data interval tergolong data kontinum yang mempunyai tingkatan yang lebih tinggi lagi dibandingkan dengan data ordinal karena mempunyai 
tingkatan yang lebih banyak lagi. Data interval menunjukkan adanya jarak antara data yang satu dengan yang lainnya.

Contoh data interval misalnya hasil ujian, hasil pengukuran berat badan, hasil pengukuran tinggi badan, dan lainnya. Satu hal yang perlu diperhatikan bahwa data interval tidak dikenal adanya nilai 0 (nol) mutlak. Dalam hasil pengukuran (tes) misalnya mahasiswa mendapat nilai 0 . Angka nol ini tidak dapat diartikan bahwa mahasiswa tersebut benar-benar tidak bisa apa-apa. Meskipun ia memperoleh nilai nol ia memiliki suatu pengetahuan atau kemampuan dalam matakuliah yang bersangkutan. Nilai nol yang diberikan oleh dosen sebetulnya hanya merupakan atribut belaka hanya saja pada saat ujian, pertanyaan yang diujikan tidak pas seperti yang dipersiapkannya. Atau jawaban yang diberikan tidak sesuai dengan yang dikehendaki soal (Emzir, 2011.).

b) Data Rasio

Data rasio merupakan data yang tergolong ke dalam data kontinum juga tetapi yang mempunyai ciri atau sifat tertentu. Data ini memiliki sifat interval atau jarak yang sama seperti halnya dalam skala interval. Namun demikian, skala rasio masih memiliki ciri lain. Pertama harga rasio memiliki harga nol mutlak, artinya titik nol benar-benar menunjukkan tidak adanya suatu ciri atau sifat. Misalnya titik nol pada skala sentimeter menunjukkan tidakadanya panjang atau tinggi sesuatu. Kedua angka skala rasio memiliki kualitas bilangan riel yang berlaku perhitungan matematis (Sujadi, 2003).

Contohnya : berat badan Rudi $70 \mathrm{~kg}$, sedangkan Saifullah $35 \mathrm{~kg}$. Keadaan ini dapat dirasiokan bahwa berat badan Rudi dua kali berat badan Saifullah. Atau berat badan Saifullah separuh dari berat badan Rudi. Berbeda dengan data interval misalnya Rudi ujian dapat 70 sementara Saifullah memperoleh 30. Hal ini tidak dapat diartikan bahwa kepandaian Rudi dua kali lipat kepandaian Saifullah. Data rasio dalam ilmu-ilmu sosial jarang dipergunakan, bahkan hampir tidak pernah dipergunakan. Lapangan penggu naan data berskala rasio ini lebih banyak berada dalam bidang ilmu-ilmu eksakta terutama fisika.

Sedangkan dalam statistik non parametris analisi data dibagi menjadi:

a) Data Nominal

Data ini juga sering disebut data diskrit, kategorik, atau dikhotomi. Disebut diskrit karena ini data ini memiliki sifat terpisah antara satu sama lainnya, baik pemisahan itu terdiri dari dua bagian atau lebih; dan di dalam pemisahan itu tidak terdapat hubungan sama sekali. Masing-masing kategori memiliki sifat tersendiri yang tidak ada hubungannya dengan kategori lainnya. Sebagai misal data hasil penelitian dikategorikan kedalam kelompok "ya" dan "tidak" saja. Contohnya :

1. Laki-laki/wanita (laki-laki adalah ya laki-laki; dan wanita adalah “tidak laki-laki”), kawin /tidak kawin; janda/duda, dan lainnya.

2. Jenis pekerjaan dapat digolongkan secara terpisah menjadi pegawai negri, pedagang, dokter, petani, buruh dsb.

3. Nomor punggung pemain sepak bola, nomor rumah, nomor plat mobil dan lainnya. Nomor-nomor tersebut semata-semata hanya menunjukkan simbol, tanda, atau stribut saja.

4. Suku, golongan drah, jenis penyakit, bentuk atau konstitusi tubuh

b) Data Ordinal

Data ordinal adalah data yang menunjuk pada tingkatan atau penjenjangan pada sesuatu keadaan. Berbeda dengan data nominal yang menunjukkan adanya perbedaan secara kategorik, data ordinal juga memiliki sifat adanya perbedaan di antara obyek yang dijenjangkan. Namun dalam perbedaan tersebut terdapat suatu 
kedudukan yang dinyatakan sebagai suatu urutan bahwa yang satu lebih besar atau lebih tinggi daripada yang lainnya.Kriteria urutan dari yang paling tinggi ke yang yang paling rendah dinyatakan dalam bentuk posisi relatif atau kedudukan suatu kelompok. Contoh dari data ini misalnya:

1. Prestasi belajar siswa diklasifikasikan menjadi kelompok "baik", "cukup", dan "kurang", atau ukuran tinggi seseorang dengan "tinggi", "sedang", dan "pendek"

2. Hasil ujian mahasiswa peserta kuliah Statistik Pendidikan Budiman memperoleh skor 90, Rahmat 85, Musyafak 75, dan Mahsunah 65. Berdasarkan skor-skor tersebut dibuatlah suatu jenjang (rangking), sehingga terjadilah urutan jenjang ke 1 (90), ke 2 (85), ke 3 (75), dan ke 4 (65). Data ordinal memiliki harga mutlak (dapat diperbanding kan) dan selisih perbedaan antara urut-urutan yang berdekatan bisa tidak sama.

\section{Proses Analisis Data}

Analisis data dalam penelitian kualitatif dilakukan sejak sebelum memasuki lapangan, selama di lapangan, dan setelah selesai di lapangan (Nana Sudjana, 2000). Dalam hal ini Nasution menyatakan analisis telah dimulai sejak merumuskan dan menjelaskan masalah, sebelum terjun kelapangan, dan berlangsung terus sampai penulis hasil penelitian (Ibrahim Bafadal, tt).

a. Analisis sebelum di lapangan

Penelitian kualitatif telah melakukan analisis data sebelum peneliti memasuki lapangan. Analisis dilakukan terhadap data hasil studi pendahuluan, atau data sekunder, yang akan digunakan untuk menentukan fokus penelitian. Namun demikian fokus penelitian ini masih bersifat sementara, dan akan berkembang setelah peneliti masuk dan selama di lapangan.

b. Analisis data di lapangan model Miles and Huberrman
Miles and Huberrman, mengemukakan bahwa aktivitas dalam analisis data kualitatif dilakukan secara interaktif dan berlangsung secara terus menerus sampai tuntas,sehingga datanya sudah jenuh, aktivitas dalam analisis data yaitu:

a) Data Reduction (reduksi data)

Mereduksi data berarti merangkum memilih hal-hal yang pokok,memfokuskan pada hal-hal yang penting. Di cari pola dan temanya. Dengan demikian data yang telah direduksi akan memberikan gambaran yang lebih jelas dan memperuah peneliti untuk melakukan pengumpulan data dapat di bantu dengan peralaan elektronik seperti komputer mini, dengan memberikan kode pada aspek-aspek tertentu, data yang tidak penting yan $\mathrm{g}$ diilustrasikan dalam bentuk simbulsimbul seperti sedangkan data yang penting diberi kode huruf besar atau huruf kecil, angka dan simbol-simbol yang mudah dipahami (Noeng Muhajir, 1996).

b) Data Display (Penyajian Data)

Setelah data direduksi, maka langah selanjutnya adalah mendisplaykan data. Kalau dalam penelitian kuantitatif penyajian data ini dapat dilakukan dalam bentuk tabel, grafik, phie chard, pictrogram dan sejenisnya. Melalui penyajian data tersebut maka data terorganisasikan, tersusun dalam pola hubungan sehingga akan semakin mudah dipa hami. Miles and Huberrman menyatakan yang paling sering digunakan untuk menyajikan data dalam penelitian kulitatif adalah dengan teks yang berifat naratif, disarankan,dalam melakukan display data, selain dengan teks naratif, juga dapat berupa,grafik,matrik, network dan chart.

c) Conclusion Drawing

Miles and Huberrman menyatakan langkah selanjutnya adalah penarikan kesimpulan dan verifikasi. Kesimpulan awal yang dikemukakan masih bersifat 
sementara, dan akan berubah bila tidak ditemuan bukti-bukti yang kuat yang mendukung pada tahap pengumpulan data berikutnya. Tetapi apabila kesimpulan yang dikemukakan pada tahap awal di dukung oleh bukti -bukti yang valid dan konsisten saat peneliti kembali ke lapangan mengumpulkan data , maka kesimpulan yang dikemukakan merupakan kesimpulan yang kresibel.

c. Analisis Data Selama di Lapangan Model Spradley

Proses penelitian kualitatif setelah memasuki lapangan,di mulai dengan menetapokan seseorang infroman kunci yang merupakan informan yang berwibawa dan dipercaya mampu membuka pintu untuk memasuki obyek penelitian.terdapat tahapan analisis data yang dilakukan dalam penelitian kualitatif:

a) Analisis domain artinya memperoleh gambaran yang umum dan menyelruh dari objek/penelitian atau situasi sosial. Ditemukan berbagai domain atau kategori. Diperoleh dengan penyataan grand dan miniour.peneliti nemempatkan domain tertentu sebagai pijakan untuk penelitian selanjutnya. Makin banyak domain yang dipilih ,maka akan semakin banyak waktu yang diperlukan untuk penelitian.

b) Analisis Taksonomi, domain yang dipilih tersebut selanjutnya dijabarkan menjadi lebih rinci, untuk mengetahui struktur internalnya, dilakukan dengan observasi terfokus.

c) Analisis Komponensial,mencari ciri spesifikpada tiap struktur internal dengan cara mengkontraskan antar elemen.di lakukan melalui observasi dan wawancara terseleksi dengan pertanyaan yang mengontraskan.

d) Analisis tema kultural , mencari hubungan diantara domain dan bagaimana hubungan dengan keseluruhann, dan selanjutnya dinyatakam kedalam tema/judul penelitian (Sugiono, 2014).

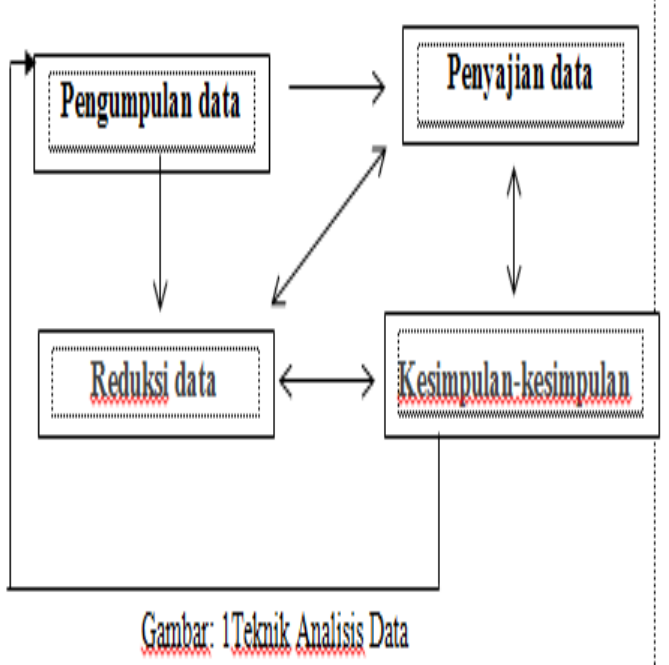

4. Langkah-Langkah Analisis Data

Sebelum data dianalisis, data kasar ada yang perlu diadministrasi secara jelas untuk memudahkan ketika seorang peneliti melakukan analisis dan merumuskanya ke komputer. Langkah ini disebut mempersiapkan data, langkah yang penting yang perlu diambil dalam mempersiapkan ini adalah:

a. Melakukan skoring

Cara menskor yang paling baik adalah dengan dilakukan secara manual.karena lebih teliti dan memiliki sensivitas tinggi bila terjadi penyimpangan. Akan tetapi dalam jumlah yang besar seperti pengambilan skor dari hasil angket ujian masuk ke perguruan tinggi, misalnya cara yang paling cepat adalah menggunnakan jasa komputer. Untuk mencapai tujuan tersebut format angket disusun sedemikian rupa sehingga mesin komputer dapat membaca dengan mudah. Persiapan tersebut termasuk menggunakan pensil tertentu dan kertas yang format dan besarnya sudah tertentu pula. Prinsip metode melakukan skoring , baik yang dilakukan manual maupun komputer adalah sama. Yang perlu diperhatikan dalam skoring adalah perlu adanya ketepatan yang tinggi atau dengan kata lain,kesalahan yang ditimbulkan oleh prosedur soring harus minimal (Sukardi, 2003). 
b. Persiapan

a) Mengecek nama dan kelengkapan indentitas pengisi

b) Mengecek kelengkapan data

c) Mengecek macam isian data

c. Tabulasi

a) Memberikan skor terhadap item item yang prli diberi sekor.

b) Memberikan kode terhadap itemitem yang tidak diberi skor.

c) Mengubah jenis data, disesuikan atau di modifikasi dengan teknik analisis yang akan digunakan.

d) Memberi kode dalam hubungan dengan pengolahan data jika akan menggunakan komputer

d. Penerapan data sesuai dengan pendekatan penetian

Pengolahan data yang diperoleh dengan menggunakan rumus-rumus atau aturn yang ada, sesuai den gan pendekatan penelitian. Untuk mempermudah cara mengikti uraian pengolahan data,kan disajikan degan sistematika yang telah dikemukakan pada bab IV mengenai jenis-jenis pemasalahan angg teah diajukan:

a) Problema untuk mengatahui status dan mendeskipsikan fenomena.

b) Problema komparasi,aitu problem yang bertujuan untuk membandngkan dua fenomena atau lebih.

c) Problema untuk mencari hubungan antara dua fenomena yang keduanya sejajar (bukan merupakan sebab akibat).

d) Problema untuk melihat pengaruh ssuatu treatmen atau ingin melihat hubungan antara variabel bebas dengan variabel terikat (Suharsimi Arikunto, 2006).

\section{KESIMPULAN}

Penelitian Research and

Development adalah suatu langkah untuk mengem bangkan suatu produk baru atau menyempurnakan produk yang sudah ada dan menguji keefekitifannya, serta bersifat longitudinal atau bertahap dapat multy years. Penelitian Research and
Development menggunakan teknik analisis data kuantitatif dan kualitatif. Pemilihan teknik analisis data ini sangat tergantung pada jenis data dan tujuan penelitiannya. 1. Teknik analisis data kualitatif terbagi menjadi dua, yaitu : (1) teknik kualitatif hanya mendeskripsikan fenomena atau fakta saja tanpa memberi makna atas fenomena tersebut., (2) teknik kualitatif yang bertujuan memaknai fenomena atau fakta secara mendalam. 2 . Teknik analisis data kuantitatif yang menggunakan statistika sebagai instrumennya dibedakan menjadi dua, yaitu: (1) analisis data kuantitatif dengan teknik statistik deskriptif, dan (2) analisis data kuantitatif dengan statistik inferensial

\section{REFERENSI}

Anik Ghufron, Panduan Penelitian Dan Pengembangan Bidang Pendidikan dan Pembelajaran. Yogyakarta: Lembaga Penelitian UNY, 2007

Anonim. karakteristik-r-research-anddevelopment. $\quad$ ttp://www. eurekapendidikan .com, 2014. Diakses pada tanggal 2 Desember 2021

Anonim. metodologi-penelitianpendidikan/educational-researchanddevelopment -rd/feed/". https://ikamakoto.wordpress.com, 2010. Diakses pada tanggal 2 Desember 2021

Anonim. Penelitian kuantitatif. https://youdant.wordpress.com, 2011. Diakses pada tanggal 2 Desember 2021

Arief Furchan, Pengantar Metode Penelitian Kualitatif, Surabaya: Usaha Nasional, 1992

Borg. W.R. dan Gall, M.D.Educational Research: An Introduction, New York: Longman, 1983

Citra, Shilvia R. penelitianpengembangan. http://shilviacitrarusti.blogspot.co.i d, 2012, Diakses pada tanggal 2 Desember 2021 
Dick and Carey, The Systematic Dessign of Instuction, New York :Harper Collins Publishers, 2001

Emzir. Metodologi Penelitian Pendidikan. Jakarta: Raja Grafindo Persada. Magfirah. penelitian-dan-pengembangan. http://magfirahrasyid. blogspot. co.id, 2011

Endang Mulyatiningsih, Metode Penelitian Terapan Bidang Pendidikan. Bandung: Alfabeta, 2012

Ibrahim Bafadal, Teknik Analisis Data Penelitian Kualitatif, (dalam Metodologi Penelitian Kualitatif : Tinjauan Teoritis dan Praktis), Malang : Lembaga Penelitian UNISMA, $\mathrm{tt}$

Lexy J Moleong, Metodologi Penelitian Kualitatif, Bandung: PT Remaja Rosdakarya, 2005

Nana Sudjana, Awal Kusumah, Proposal Penelitian di Perguruan Tinggi, Bandung: PT Sinar Baru Algensindo, 2000

Nana Syaodih Sukmadinata, Metode Penelitian Pendidikan. Bandung : Remaja Rosdakarya 2009

Noeng Muhajir, Metode Penelitian Kualitatif, Yogyakarta: Rake Sarasen, 1996

Nuruddin, Khasan. makalah-analisiskebutuhan. http:// asakhasan. blogspot. co.id, 2014. Diakses pada tanggal 2 Desember 2021

Prasetyo, Teknik Analisis Data dalam Research and Development. (UNY: Fakultas Ilmu Pendidikan, 2012

Punaji Setyosari, Metode Penelitian Penelitian dan Pengembangan. Jakarta: Kencana, 2010

Rouf, Muhammad. analisis-datapenelitian.http://rouf250389.blogsp ot.co.id, 2014. Diakses pada tanggal 2 Desember 2021

Setiawan, Andri. metode-penelitian-rresearch-and. http:// andristiawan. blogspot. co.id, 2014.
Sawaluddin, dan Muhammad Siddiq, Langkah-Langkah Dan Teknik Evaluasi Hasil Belajar Pembelajaran Agama Islam. Jurnal PTK \& Pendidika, 2020. vol 6. No 1

Singarimbun, Masri dan Sofian Effendi, Metode Penelitian Survei, Jakarta: LP3ES, 2008

Sudarwan Danim, Menjadi Penulis Kualitatif, Bandung: CV. Pustaka Setia, 2002

Sugiyono, Metode Penelitian Kuantitatif, Kualitatif dan R\&D. Cetakan ke-5. Bandung: CV. Alfabeta, 2009 , Metode Penelitian Kuantitatif, Kualitatif dan R\&D. Jakarta : Alfhabeta, 2001 Metode Penelitian Kuantitatif,Kualitatif, dan $R \& D$, Bandung: Alfabeta, 2014

Suharsimi Arikunto, Prosedur Penelitian Suatu Pendekatan Praktik, Jakarta: PT Asdi Mahastya, 2006

Sujadi, Metodologi Penelitian Pendidikan. Jakarta. Rineka cipta, 2003

Sukardi, Metodologi Penelitian Pendidikan komptensi dan Praktiknya, Jakarta: PT Bumi Aksara, 2003

Suprayogo Imam, Tobroni. Metodologi Penelitian Sosial Agama. Bandung : PT Remaja Rosdakarya, 2001

Van den Akker J. Principles and Methods of Development Research. Pada J. van den Akker, R.Branch, K. Gustafson, Nieven, dan T. Plomp (eds), Design Approaches and Tools in Education and Training, 1999

Zainal Arifin, Penenlitian Pendidikan Metode dan Paradigma Baru. Bandung: Remaja Rosda Karya, 2012

Sawaluddin, dan Muhammad Siddiq, Langkah-Langkah Dan Teknik Evaluasi Hasil Belajar Pembelajaran Agama Islam. Jurnal 
Journal of Islamic Education El Madani

Volume 1. Nomer 1. Desember 2021

PTK \& Pendidika, 2020. vol 6. No 1 